This item was submitted to Loughborough's Research Repository by the author.

Items in Figshare are protected by copyright, with all rights reserved, unless otherwise indicated.

\title{
New regional geographies of the world as practised by leading advanced producer service firms in 2010
}

PLEASE CITE THE PUBLISHED VERSION

http://dx.doi.org/10.1111/j.1475-5661.2012.00545.x

\section{PUBLISHER}

Blackwell Publishing ( ) The Author. Transactions of the Institute of British Geographers @ Royal Geographical Society (with the Institute of British Geographers)

\section{VERSION}

AM (Accepted Manuscript)

\section{LICENCE}

CC BY-NC-ND 4.0

\section{REPOSITORY RECORD}

Taylor, Peter J., Ben Derudder, Michael Hoyler, and Pengfei Ni. 2019. "New Regional Geographies of the World as Practised by Leading Advanced Producer Service Firms in 2010". figshare.

https://hdl.handle.net/2134/12511. 
This item was submitted to Loughborough's Institutional Repository (https://dspace.lboro.ac.uk/) by the author and is made available under the following Creative Commons Licence conditions.

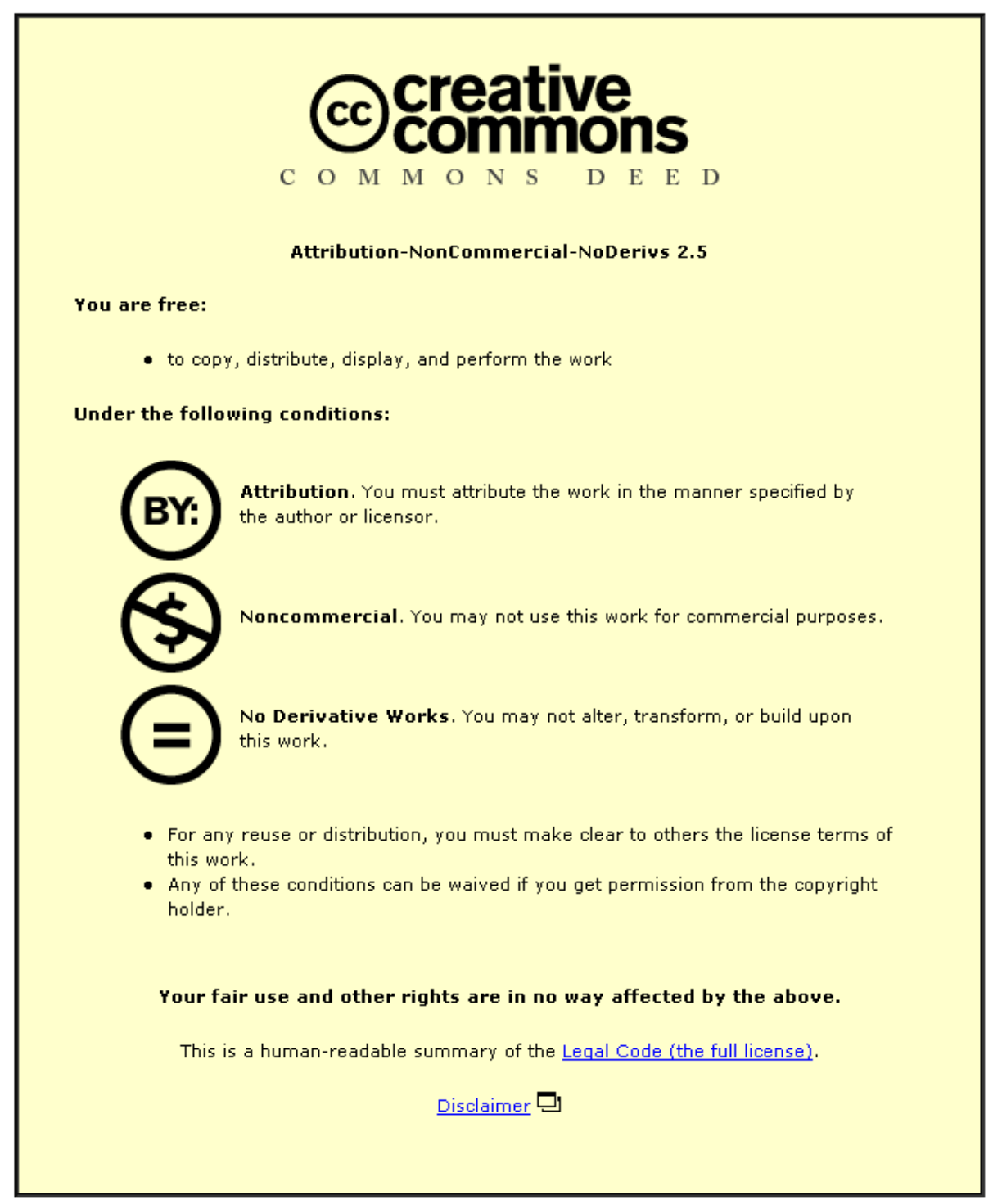

For the full text of this licence, please go to: http://creativecommons.org/licenses/by-nc-nd/2.5/ 


\title{
New regional geographies of the world as practised by leading advanced producer service firms in 2010
}

\author{
Peter J. Taylor ${ }^{1}$, Ben Derudder ${ }^{2,3}$, Michael Hoyler ${ }^{4}$ and Pengfei $\mathrm{Ni}^{5}$ \\ ${ }^{1}$ School of Built and Natural Environment, Northumbria University, Newcastle upon \\ Tyne NE1 8SP, UK \\ ${ }^{2}$ Department of Geography, Ghent University, Ghent, Belgium \\ ${ }^{3}$ School of Geography and Environmental Science, Monash University, Clayton, \\ VIC3800, Australia \\ ${ }^{4}$ Department of Geography, Loughborough University, Loughborough LE11 3TU, UK \\ ${ }^{5}$ Chinese Academy of Social Sciences, Beijing, China
}

\begin{abstract}
This paper reports a new type of world regionalisation based upon the location strategies of leading advanced producer service firms. To generate these 'global practice' regions, a principal components analysis of the office networks of 175 service firms across 138 cities is used to identify 10 common location strategies. These are interpreted as fuzzy (overlapping) and porous regional formations each consisting of two parts: a home-region and a global-outreach. The results indicate five overlapping pairs of regions: (i) intensive and extensive globalisations based upon the USA plus London (USAL); (ii) Americas and Latin America regions; (iii) Pacific Asia and China regions; (iv) Europe and Scandinavia regions; and (v) Australasian and Canadian 'Commonwealth' regions. All regions have worldwide globaloutreaches but they differ significantly in their respective sizes and importance. Discussion of these findings elaborates upon two key points: first, globalisation is not a 'blanket' process creating a homogeneous world, and second, the resulting fuzzy and porous regionalisation counters the traditional 'territorialist' regional geographies that can provide a framework for global conflict with a more complex geography of multiple global integrations.
\end{abstract}

Key words: world regions; globalisation; advanced producer services; regional geography 


\section{Introduction}

Geography has a long tradition of dividing up the world into regions for both imperial and pedagogic ends. Such world regions continue to be a key feature of geographical textbooks. However apart from Lewis and Wigen's (1997) assault on the anachronistic continuous use of 'continents' to frame global conversations, there appears to have been little critical thought applied to world regionalisation within contemporary globalisation. John Agnew has recently suggested a reason for this: he posits a curious paradox that contemporary globalisation has been accompanied by 'the declining relevance of regional schemas at that scale' (2012, 2). Agnew is certainly correct in pointing out that studies of regions in globalisation have focused upon the 'meso scale regions' based upon cities (e.g. Scott 1998; Amin 2004; Florida 2008), but this should not preclude investigating regionalisation at the global scale itself. Thus we doubt the veracity of Agnew's paradox and this paper addresses this lacuna in the literature by focusing on selected key agents who facilitate the reproduction of globalisation, specifically advanced producer service firms and their worldwide networking activities. In carrying out their everyday work, many of these firms have devised global strategies through which new regional formations are being constructed. We uncover these regional structures and interpret them as a very different form of spatial organisation than has been previously identified as world regions.

As part of the Globalization and World Cities (GaWC) research programme (www.lboro.ac.uk/gawc) we have been monitoring the world city network since 1998. One robust feature of our analyses stands out. The results always show strong regional patterns of cities within different statistical analyses whether using principal components analysis (Taylor and Walker 2001; Taylor et al. 2002b; Taylor 2011), multidimensional scaling (Taylor et al. 2001), discriminant analysis (Taylor 2004a), or fuzzy set analysis (Derudder et al. 2003). This particular economic globalisation process - world city network formation - does not support stories about a blanket-effect of global processes such as Friedman's (2005) 'flat world'; but neither does it support Florida's (2008) 'spiky world' riposte to Friedman. Rather, the latter world is far more 
globally ordered than Florida's study proposes: our results show new world regional geographies being created to satisfy different service provisioning. In this paper we present the regional results from our latest data on the world city network for 2010. A combination of improvement in data collection and a maturing of the global processes we are measuring have enabled us to produce our most sophisticated regional geography of globalisation thus far.

The regional geographies we describe are the antithesis of the traditional regional depictions by geographers and others imperiously trying to order their subject matter into meaningful organisation of world-space. Rather, by studying economic agents who are creating global regional patterns in the conduct of their businesses we are revealing regionalisation derived from the work of doing globalisation. Obviously the firms we study are not necessarily bent on devising regional schemes but they do partake in location decisionmaking through which regional patterns can be discerned. Leading advanced producer service firms have reacted to, and contributed to, economic globalisation through their location decisions on placing offices to service clients in cities across the world. Spatially they are network-makers rather than region-builders, but their creation of a world city network for servicing global capital inevitably reflects uneven market geographies for their services, and firms' world-regional origins. The result is a world regional geography as practised by leading advanced producer service firms.

Our practical world-regional approach chimes with ongoing debates around the nature of regional process at other scales as pioneered by Doreen Massey (1979; 1993; Allen et al. 1998) and Anssi Paasi (1986); Agnew (2012) provides the latest review of the key issues. Past empirical concern for regional delimitation, largely based upon equating regionalisation with classification, has produced regional patterns neatly demarcated as a simple, mosaic geography. It is this traditional focus on absolute boundaries that has come to be challenged by relational approaches (see Harrison 2008; Jonas 2012), which Amin (2004) refers to as 'regions unbound'. The inherent messiness of our dynamic world is becoming recognised and respected, and we follow this turnabout in identification of 'world regions unbound'. However 
we are cognisant of the need to balance flows/relations with places/fixities (Paasi 2004, 542; Jones 2009, 488). Specifically, in using Castells' (1996) social space constructs, we expect boundaries to be both fuzzy from a 'spaces of places' perspective and to be porous from a 'spaces of flows' perspective. These expectations are broadly in line with the deal of overlapping that we have found in all our previous global regional geographies. In our more refined latest results this overlapping requires us to take the argument into new conceptual realms: we have discovered an outcome where it is not only regional boundaries that are fuzzy and porous, the centres of regions are similarly fuzzy and porous. Fortunately, the overlapping appears to have a consistent characteristic that aids our interpretation.

To understand this unforeseen degree of overlap we have devised a customised regional framework consisting of two operational realms: homeregion and global-outreach. Typically, the agents of the regionalisation, advanced producer service firms, have a regional concentration of servicing provision relating to their region of origin and headquarter location, plus a dispersed worldwide distribution of service provision marking their globalising strategy. To describe this 'home and away' geography we introduce the following definitions.

1. The simplest concept is home-region, a geographical concentration of cities through which a common set of services are directed and provided. However it is important not to view this as indicating a territory filled by like-cities forming a homogenous space. There can be cities in the home-region that are not part of the regional formation because they are relatively weak purveyors of the services otherwise dominant in the region.

2. The global-outreach is constituted by cities from outside the homeregion that form part of the location strategies of the firms responsible for the services defining the home-region. In this context we define 'global' minimally as location strategies having presence in the three dynamic globalisation arenas, the USA, Europe and Pacific Asia. All the home-regions we identify have such global-outreach. 
The prime purpose of this paper is to develop empirical definitions of these concepts and illustrate their formation in 2010.

Before we give empirical life to these constructs and illustrate them through our new results, we need to specify the model we are using and describe the consequent data collection, and we have to outline and justify the analytical techniques we employ to generate our regionalisation.

\section{World city network formation}

The research we report is based upon an extension of Saskia Sassen's (1991) concept of the global city. She argued that there were a select number of cities which were strongly associated with contemporary globalisation through their development of advanced producer services (APS) by firms offering customised financial, professional and creative expertise to corporate clients. As the latter globalised so also did the firms servicing them in areas such as commercial law, wealth management, corporate tax advice and advertising. The result was that global cities became simultaneously markets for these services through corporate presences, and production centres of these services through innovative knowledge clusters. Sassen treated London, New York and Tokyo as archetypal global cities and indicated that there were about 20 such cities in the world economy servicing global capital. It was through the expertise of APS firms in transnational servicing of their clients that global cities became seen as the organising nodes of economic globalisation.

We accept Sassen's identification of APS firms at the cutting edge of the world economy through enabling transnational commerce and production, but we extend the argument beyond just a small number of select cities. Typically, leading APS firms operate through office networks across a large number of cities, often scores in the case of law firms, sometimes hundreds in the case of advertising agencies, and even thousands of cities with the big accountancy firms. Thus we have moved away from an emphasis on a few nodes as 'global cities' to focus on the network relations of many more cities 
in the servicing of global capital. This is specified as a world city network that takes the form of an interlocking network model (Taylor 2001).

An interlocking network has an unusual network structure consisting of three rather than two levels. In most network analysis there are nodes (e.g. members of a gang) whose interactions generate a network (e.g. a gang). In such cases the nodes are the agents in the process of network formation: their inter-relations define the network. In an interlocking model the networkmaking agents are not the nodes but are to be found within the nodes thus producing three levels of operation: sub-nodal, nodal and net. In our analyses the APS firms constitute the sub-nodal; they 'interlock' cities through their everyday servicing work. It is the flows of information, knowledge, direction and advice in planning and strategic work for clients across firms' offices that create worldwide inter-city relations. These can be electronic messages, telephone conferences, face-to-face meeting through expert travel that together, across myriad APS firms, have generated a world city network. The key point is that cities are the service centres (nodes) in this model, but they are not the agents: world city network formation is the work of APS firms.

This model is operationalised through collecting data on the office networks of APS firms (Taylor et al. 2002a). These data are readily available on firms' websites where they promote their 'global' status as a means of both impressing clients in a competitive services market and recruiting graduates in a competitive jobs market. However, this source, plus supplementary information as available, produces different levels and types of information for every firm. Thus the data have to be converted into simple coding to enable cross-firm comparison for analysis. We have found that a coding from 0 to 5 has served this purpose; such numbers are called service values and measure the importance of a given city in a given firm's office network. Thus, 0 indicates a city where a firm has no presence, 5 is the firm's headquarter city. Codes 1 to 4 are then allocated as follows: a typical office of a firm scores a city 2 , there must be something deficient to lower to 1 , and something extra to rise above 2. For the latter an especially large office scores 3, an office with extra-city jurisdictions (e.g. regional HQ) scores 4. 
Each firm is assessed individually to decide on boundary decisions away from 2. With $n$ firms and $m$ cities, such data collection creates an $n$ firms $\times m$ cities service values matrix, the basic raw material for interlocking network analysis. Each column of the matrix shows a firm's location strategy as a string of 0 s to 5 s across $m$ cities; each row shows a city's service mix as a string of 0 s to $5 \mathrm{~s}$ across $n$ firms.

Such data have been collected for 2000, 2004, 2008 and 2010; it is the latter data we analyse below. In this case $n=175$ composed of 75 financial services firms and 25 each of accountancy, advertising, law and management consultancy firms. Firms were chosen using trade information ranking firms by size based upon the latest information available (e.g. on turnover) before the data collection (i.e. for 2009). In earlier data collection (2000, 2004) we only included firms having a global strategy through having offices in the USA, Europe and Pacific Asia, which we called global service firms. This approach was changed with the 2008 data for technical reasons as given in Derudder et al. (2010) and has been continued for 2010 data. This decision to change choice of firms from global reach to simply size is particularly apposite for the current study because it avoids circular reasoning: we would have been arguing that specifically selected global service firms were creating globalreach. Instead it is large firms in general, not selected for any location trait, that we have found to be generating global-reach beyond their home-regions.

The choice of cities is more straightforward. Cities were chosen on the basis of previous experience in this work (315 cities used for collecting the 2000 and 2004 data) plus all cities with more than 2 million population, all capital cities of countries with over 1 million population, and all cities recording a headquarters of one of our firms. These are arbitrary rules of inclusion, but our aim was simply to include more cities than necessary so as not to exclude any cities that might surprise us in what is a rapidly changing process of world city network formation. The end result is a 175 firms $\times 526$ cities services values matrix for 2010. There are two different approaches to analysing such data (Taylor 2004b). One approach is to convert the service values matrix into a city $x$ city matrix and carry out network analyses on inter-city relations to 
measure network connectivities. The other approach analyses the service values matrix directly in order to find structural patterns in the data (Liu and Derudder 2012). In this paper we do the latter using principal components analysis as our method of choice.

Principal components analysis (PCA) is a means of data reduction; it reduces a large data matrix into a smaller one by combining like-variables into new common variables called components. In applying this technique to a service values matrix, the firms' location strategies are the variables and therefore the components represent common location strategies constituted by groups of firms with similar office network geographies across cities. In large data sets there will always be firms with particular location strategies like no others; these will not feature in any of the common strategies. Thus a PCA interpretation will always divide the data into two parts: that identified as common (like-strategies), and the part constituted by specific (idiosyncratic) strategies. The idea is to focus on the former in the hope that just a few components account for a sizeable proportion of the variation in the data matrix. Thus PCA is a tool of parsimony that excavates common patterns within multifarious data sets, in this case common strategies from amongst the office networks of 175 leading APS firms.

There are three key pieces of information produced in the analysis:

1. Importance of components/strategies. Components are extracted from the data in order of importance defined as proportion of variance in the matrix they encompass. The idea is to focus on just the most important components.

2. Relating firms to common strategies. The degree of correlation between a firm's office network and a component/strategy is given by component loadings. As with inter-variable correlations, loadings range from +1.0 to -1.0 . The idea is to focus on firms with high positive loadings on a component. We use loadings above +0.4 to identify the types of firms generating common strategies.

3. Relating cities to common strategies. The significance of each city for a component/strategy is given by component scores. These are 
presented as standardised variables; this means they have a zero mean and scores with high positive values are deemed to indicate cities that are particularly important in a given common component/strategy. Scores above +0.5 are used to label strategies. In addition, we have taken note of cities with high negative scores because some cities are conspicuous by their absence in a given common strategy. Absences have proven to be quite instructive in some of our interpretations and we have identified the 11 lowest component scores (all below -2), which will be referred to in discussion of extreme excluded cities within the various common strategies below.

For the 2010 analysis we used 138 cities, inclusion being restricted to cities having presences of at least 35 of our 175 leading firms. A varimax rotation was employed to ensure clearly defined components called 'simple structure' (Rummel 1970, 376-81). Ten components have been extracted from the data defining ten distinctive location strategies. This reduction from 175 firms' individual strategies to 10 common strategies incorporates slightly under 55 per cent of the initial data variance. Statistically, this represents a very good reductive outcome. We interpret the ten common location strategies as world regional geographies.

\section{Common global strategies as regional geographies in $\mathbf{2 0 1 0}$}

In terms of the amount of data variance they incorporate, the components fall into three groups:

1. The two most important overlap in the long-term centre of the world economy (the USA plus London, which we call USAL); using the component scores these are labelled 'USAL Intensive' (accounting for $12.29 \%$ of the overall variance) and USAL Extensive (9.57\%);

2. The next three compose a middle group with home-regions equating to the important globalisation arenas; these are labelled Pacific Asia (6.64\%), Americas (6.08\%) and Europe (6.07\%);

3. The five relatively minor components each relating to relatively narrower home-regions; these are labelled Australia/Commonwealth 
(3.66\%), Latin America (2.73\%), Canada/Commonwealth (2.47\%), Scandinavia $(2.30 \%)$ and China $(2.29 \%)$.

These three levels of importance should be kept in mind in descriptions of components below but we choose to organise our discussion in more geographical terms. The ten strategies fall neatly into five pairs with varying degrees of overlap: the two USAL strategies, Pacific Asia and China strategies, Americas and Latin America strategies, Europe and Scandinavia strategies, and the two Commonwealth strategies. Since these overlaps represent much of the messiness that is a key feature of our particular global regionalisation, they guide our interpretation of the PCA below. The latter is based upon the component scores recorded as cartograms in Figures 1-5.

Before describing the results, there is a new feature in addition to the PCA, one that enhances interpretations compared to previous studies of service values matrices. Here we introduce an additional geography. As well as the component scores on the cities providing the usual geography of the servicing for each common strategy, there is a second geography: we have added the geography of the decisionmaking that has produced the strategy. This is derived from the headquarter locations of the firms that contribute to a given component. Weighted by their loadings and summed to cities, these provide a measure of the headquarter functions behind each common strategy. Those cities measuring 0.5 or over on this summation are designated command cities and these have been identified for all ten common strategies in Table 1.

\section{USAL strategies: intensive and extensive globalisations}

The combination of US cities and London has been central to the construction of economic globalisation and its current crisis (Wójcik 2011). We have united them in our interpretation of the home-region of the two most important components because London has both a component score and an HQ sum of over 1.5, like New York and Chicago, in both location strategies. Such dual instances are rare: there are only four other examples in the rest of the analyses all denoting the key cities in a home-region (Tokyo and Beijing in 
Pacific Asia, and Sydney and Toronto in their respective Commonwealth components).

USAL is the home-region for these two components that account for over 20 per cent of the variance in the data between them. Their service geographies are given in Figure 1. Note that it is London alone and not UK cities in general that feature in these figures. That this north Atlantic connection, a long-term central link of the world economy, defines the home-region for today's most important common strategies is in keeping with the Americanisation of the mid twentieth century being the precursor of globalisation in the late twentieth century. This is because London was integral to this process: in hindsight we can see that the City of London invention of the Eurodollar market in 1957 (Burn 2000; Kynaston 2011) was a true pioneer of contemporary globalisation with London's deregulation - 'big bang' - in 1986 consolidating the process.

The key features of the USAL intensive globalisation strategy are as follows.

- There are 50 firms pursuing this strategy, by far the most for any strategy, and they are mainly US law firms, banks and management consultancies.

- The decisionmaking geography of these firms is dominated by New York, with Chicago also very important and London in third place (Table 1).

- The servicing geography is largely restricted to the home-region and here there are eight cities leading the provisioning.

- The global-outreach is very selective, focusing on only the most important cities in the two other key global regions: Brussels, Frankfurt and Paris in Europe and Beijing, Hong Kong and Tokyo in Pacific Asia.

Labelling of this strategy as intensive globalisation is spatially derived from a combination of service concentration in the USAL home-region plus targeted selectivity in global-outreach. 


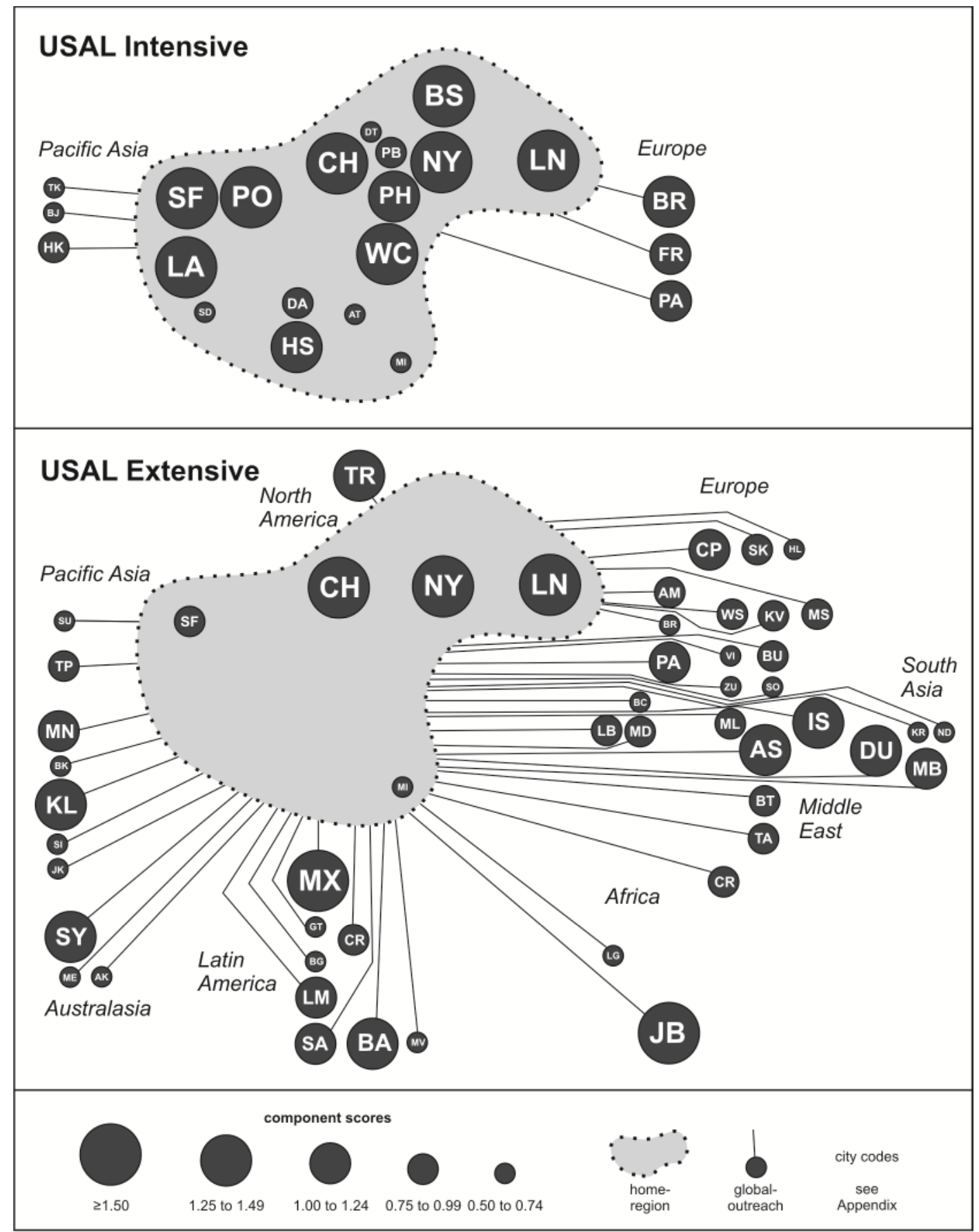

Figure 1 USAL globalisation strategies. Note: City codes are given in the Appendix

The key features of the USAL extensive globalisation strategy are as follows.

- There are 26 firms pursuing this strategy, mostly advertising agencies that typically have large worldwide office networks. 
- However, the decisionmaking geography of this strategy is very concentrated, featuring only four cities and dominated by New York (Table 1).

- The USAL home-region has three of the five leading service provision cities - Chicago, London and New York - but includes only two other cities. In fact the home-region includes an extreme excluded city: Baltimore represents the hollowing out of the USA in this strategy wherein most US cities are missing.

- In the global-outreach, Johannesburg and Mexico City are the other two leading service provision cities, but the main feature is that this outreach includes far more cities than any other strategy and covers all parts of the world.

Labelling of this strategy as extensive globalisation is spatially derived as the obverse of intensive globalisation from a combination of targeted service concentration in the USAL home-region plus comprehensive coverage in global-outreach.

Identification of contrasting intensive and extensive globalisations has been previously made using dyad analyses with the 2008 service values data matrix (Taylor et al. 2011); as well as confirming this interesting finding, the present analysis has located London at the centre of these processes. Clearly the 'home' of contemporary globalisation, USAL has been the locus for generating these two distinctive globalisation strategies. It seems that even the globalisation emanating from the economic heartland of the world economy refutes any notion that there is a single global process homogenising the world.

\section{American strategies: regional and inter-regional geographies}

The components centred on USAL are not the only common strategies emanating from US command and service provision: there is an additional strategy that encompasses other parts of the Americas and a minor strategy that emanates from Latin America. 


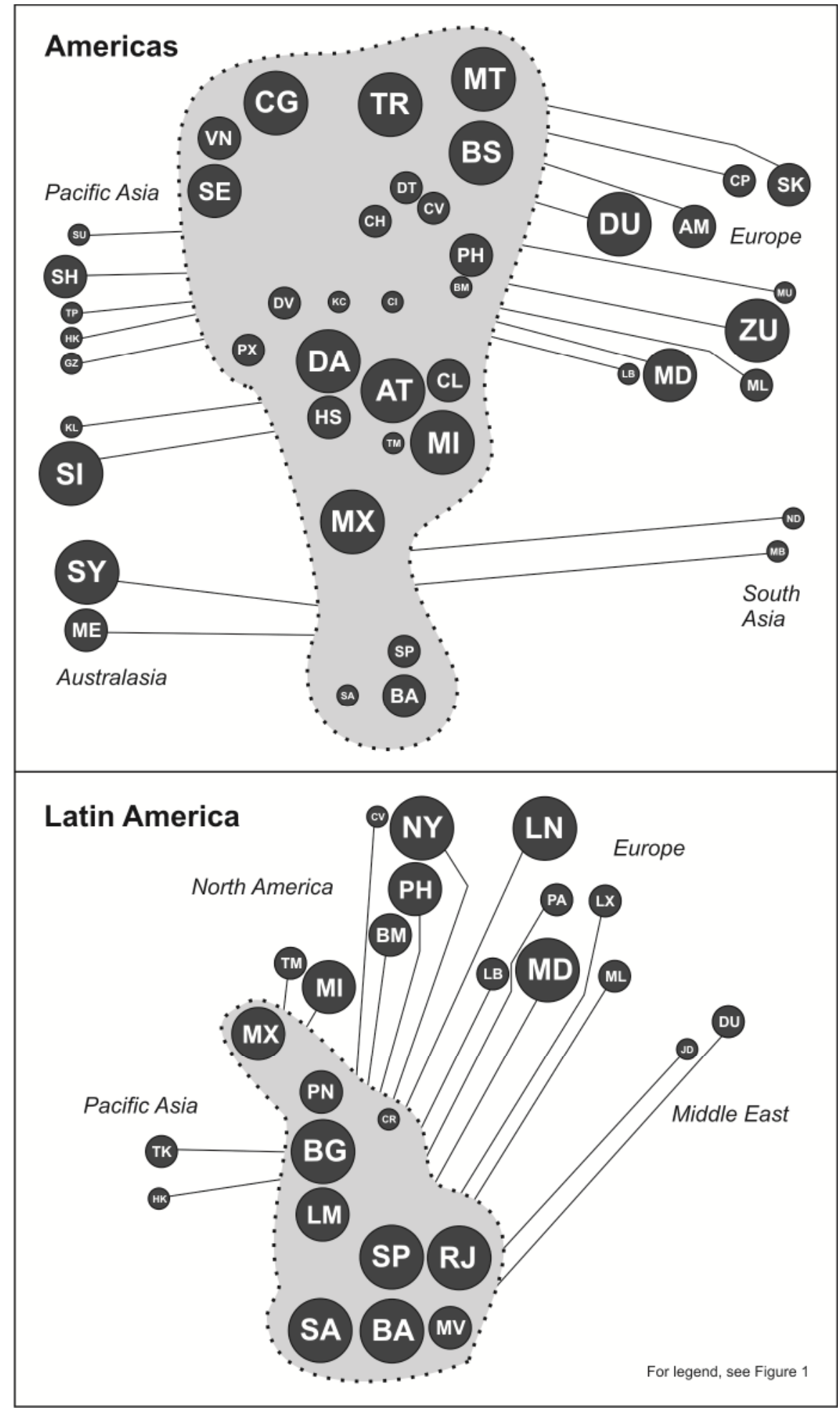

Figure 2 Americas strategies. Note: City codes are given in the Appendix and the key is in Figure 1

The key features of the Americas common strategy are as follows.

- There are 22 firms pursuing this strategy, largely US consultancy firms and financial services. 
- However, once again New York dominates the command cities (Table 1) but without London, and with Chicago ranked third. Toronto is the second most important command.

- The relative importance of Toronto in this strategy is confirmed by the service provision geography, a home-region that features all four Canadian cities in our data, with three being highest category cities (Figure 2a). But the home-region is focused on US cities with 17 included and four in the highest category. The latter are very different from the USAL service geographies: Boston and three southern cities Atlanta, Dallas and Miami. Intriguingly, neither New York nor London feature in this provision geography. In addition there is an extreme excluded US city: the high tech centre of Palo Alto is most certainly not part of this strategy. Completing the home-region, there are four Latin American cities in the servicing geography.

- The global-outreach is largely to Europe and Pacific Asia but cities from both South Asia and Australasia are also featured.

Labelling of this strategy as Americas is spatially derived from the inclusion of both Canadian and Latin American cities in the home-region.

The key features of the smaller and more specific Latin American common strategy are as follows.

- There are five firms pursuing this strategy, all financial service firms.

- There are two Brazilian command cities - São Paulo and Brasilia plus Madrid (Table 1).

- The resulting service geography is strongly focused on the Latin America home-region in which all ten cities in the data are featured, five of them with highest category scores (Figure 2b).

- There are three highest category cities in the global-reach, London and New York, plus Madrid. There are also five other US cities in this service geography, and four other cities from Western Europe plus two each from Pacific Asia and the Middle East. Finally, this strategy has two extreme excluded cities both of which are interesting: Chicago, 
confirming this city's restriction largely to a USAL role, and Beijing, confirming the relative weakness of this strategy in the important global region of Pacific Asia.

The addition of these American common strategies to the USAL strategies illustrates the complexity of this practical regional geographical exercise with its extreme excluded US cities and the different uses of New York and London. But all this is in keeping with the USA role in generating and promoting economic globalisation. However, there are more common strategies not including the USA as part of a home-region, six out of ten, showing that globalisation is geographically so much more than earlier Americanisation of the world economy.

\section{Asian strategies: dual roles for Chinese cities}

Spinning around to the other side of the globe, there are two intriguing common strategies that are even more contrasting than those of the previous discussions. The Pacific Asia component is a well-established common strategy and has featured in all earlier analyses of service values matrices. In contrast, this is the first PCA that has identified a specific China strategy. Studies of network connectivity have shown the increasing importance of Chinese cities, specifically Beijing and Shanghai in 2004 (Taylor and Aranya 2008) and in 2008 (Derudder et al. 2010; Hanssens et al. 2011), and it appears that this has finally developed into a distinctive common strategy in 2010. One result of the quite different provenances of these two strategies is that they are very different in size: Pacific Asia ranks third in importance and China enters the list in tenth place. 


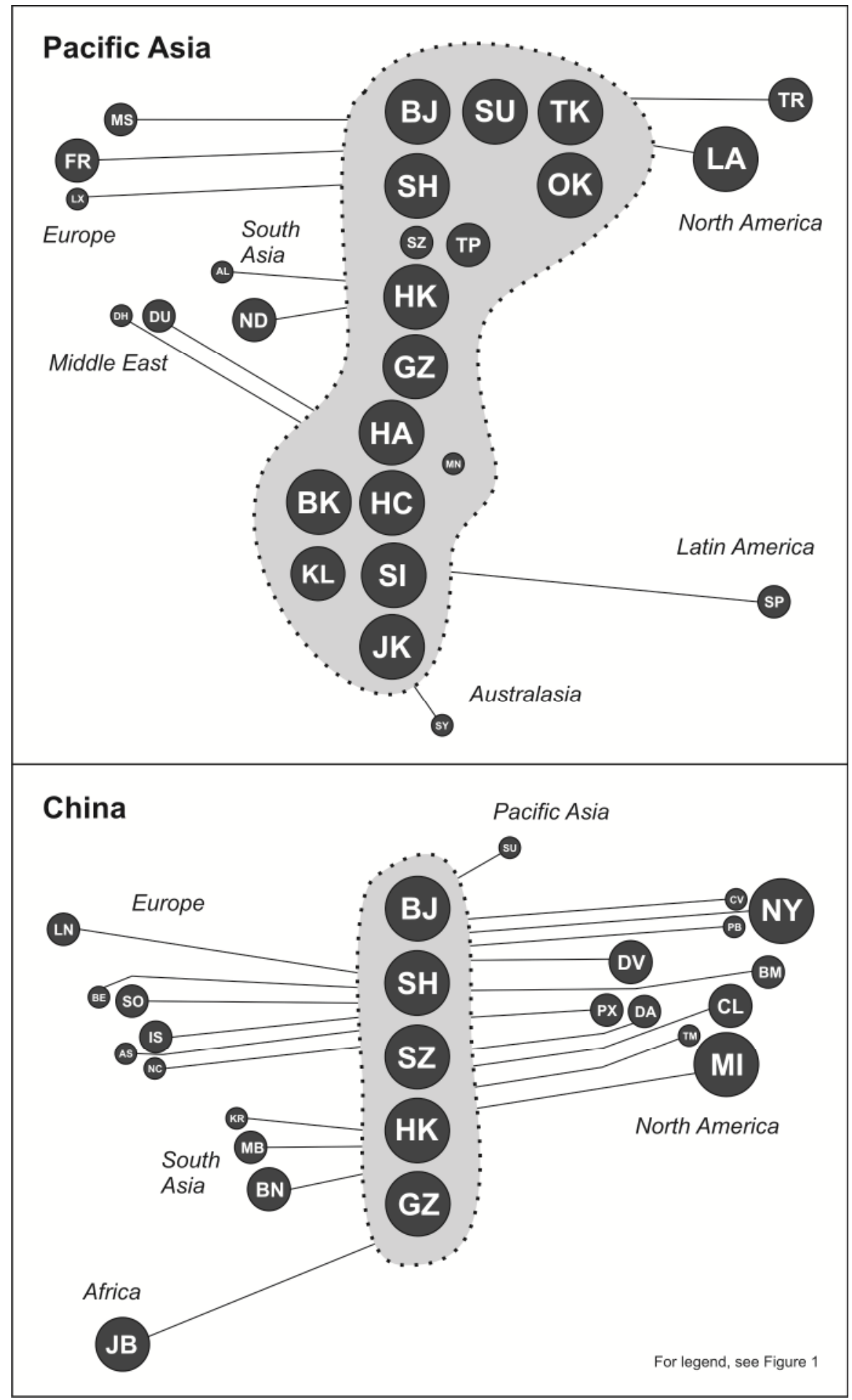

Figure 3 Asia strategies. Note: City codes are given in the Appendix and the key is in Figure 1

The key features of the Pacific Asia common strategy are as follows.

- There are 19 firms pursuing this, mainly Japanese banks and advertising agencies. 
- This is reflected by the massive dominance of Tokyo among command cities, above other home-region cities - Beijing, Seoul and Singapore (Table 1). It is noteworthy that the list of command cities also includes three cities from the global-outreach (London, Paris and Melbourne).

- In the geography of the actual service provisioning, this strategy totally covers its home-region where every city is strongly featured: of the 16 Pacific Asian cities included in the analysis, fully 12 of them are in the highest component scores category (Figure 3a).

- In contrast there is only one global-outreach city in this highest category (Los Angeles). But there are ten further outreach cities and they show a quite distinctive and relatively even global geography: four are elsewhere in Asia (two in South Asia, two in the Middle East), three are in Europe, one other in North America, one in Latin America and one in Australasia.

The key features of the smaller and more specific China common strategy are as follows.

- There are five firms pursuing this strategy, all from financial services.

- There are just three command cities, all Chinese (Table 1).

- In the geography of servicing provision, all five Chinese cities fall into the highest component score category (Figure 3b). This is a China-only home-region and its separation from the rest of Pacific Asia is shown by the fact that with only one exception, Pacific Asian cities do not even feature in the global-outreach. This is emphasised by the fact that Tokyo, the leading city of the Pacific Asia common strategy, features as an extreme excluded city in this strategy, as does Taipei, a Chinese world city but not administered by China.

- The China strategy also differs sharply from the Pacific Asia strategy in the size of its global-reach: 21 cities, which is almost twice the number in the Pacific Asia strategy. The China global-reach is concentrated in the USA, where both New York and Miami feature as highest component score cities. In the latter case, this may represent an alternative Latin American penetration since no cities from that region 
feature in this service geography. In Western Europe there is just London featured (remember neither London nor New York are in the Pacific Asia service geography). However, Eastern Europe is represented by five cities, South Asia by three cities and Africa by one city, Johannesburg, which is notably important as the only second highest component score category city in this geography.

Clearly a very distinctive servicing geography, it appears to reflect Chinese overseas past, present and possible future investments.

The discovery of this Chinese common strategy in 2010 is an intriguing finding that may well portend a much more important strategy in future world city network development. This is a clear case of overlapping regions, since all the Chinese cities are featured in the Pacific Asia home-region, while also constituting their own home-region. By carving out its own strategic geography of home-region and global-reach, this suggests that China is not simply another Pacific Asian 'development state' to come to the fore in a globalising world economy. Neither is it simply a rival to Japan in the Pacific Asian regional-economy; rather it represents a new intervention in the world city network that transcends Pacific Asia, perhaps even suggesting a possible future rival of USAL.

\section{European strategies: mainstream and peripheral}

Back in the traditional centre of the world economy, indeed its initial core zone, Europe is represented by two common strategies. However, they are not as might be predicted. In general, there are two familiar regional divisions of Europe: an East-West contrast that historically culminated in the Cold War division; and an equally old North-South division, the Mediterranean world and beyond the Alps. Both of these divisions have been based upon roughly equal parts of Europe. Not so our identification of contemporary global strategies wherein the two home-regions are of very different magnitudes as reflected in their labels: an almost inclusive Europe strategy and a small northern Scandinavian strategy. 


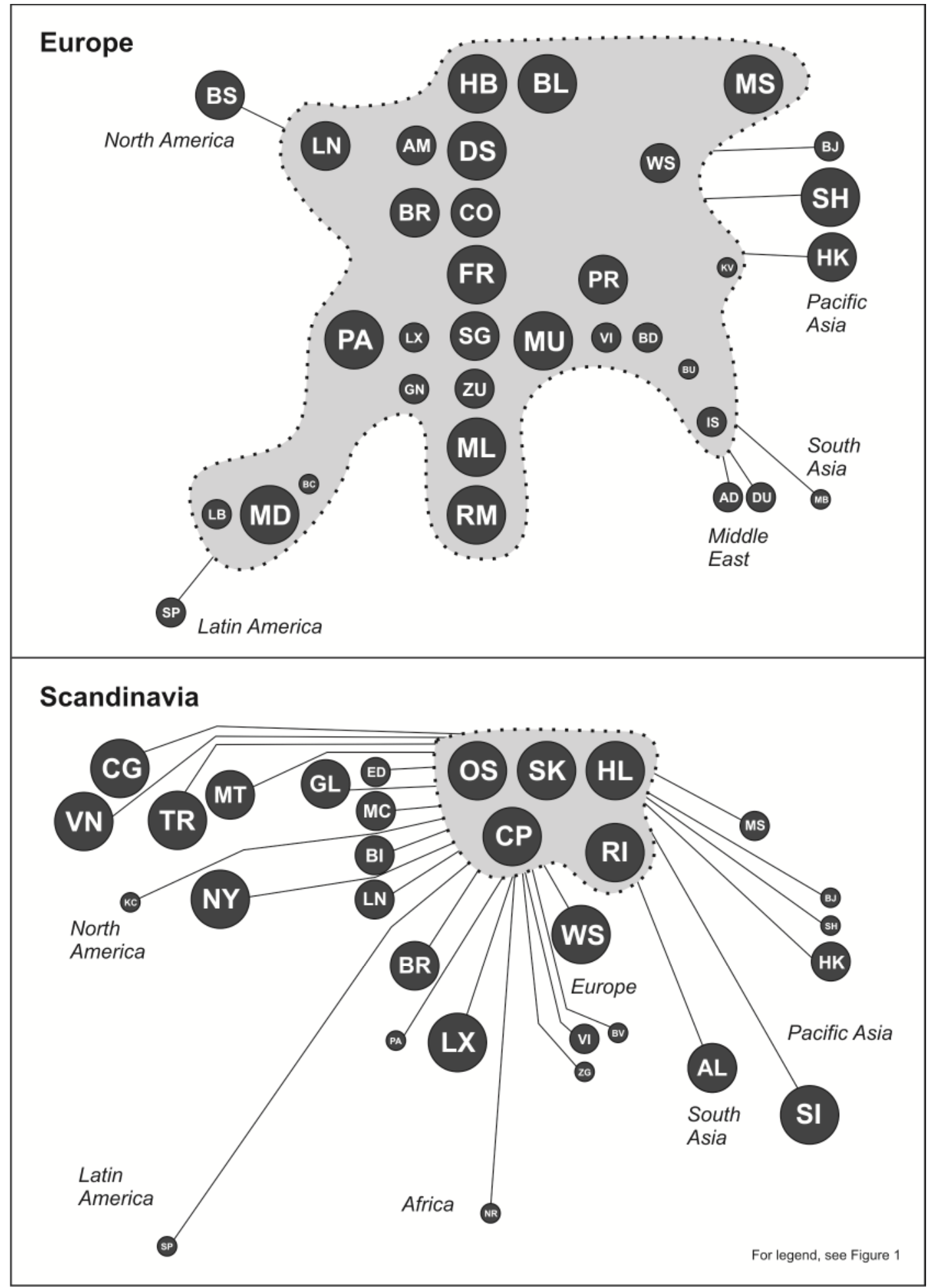

Figure 4 Europe strategies. Note: City codes are given in the Appendix and the key is in Figure 1 
The key features of the Europe common strategy are as follows.

- There are 20 firms pursuing this strategy dominated by London law firms and more broadly including European financial services (but not from London) and European consultancies.

- This is reflected in the command cities where London dominates but eight other European cities appear from across the continent (Table 1).

- This widespread home-region pattern is confirmed and elaborated in the service provision geography (Figure 4a). Here we find a German city concentration (five of seven German cities in the data) in the highest scoring category, together with Paris, plus Madrid, Milan and Rome from the South and Moscow from the East.

- There is also one highest category city in the global-outreach: Shanghai. This city indicates a location strategy that focuses on China - Beijing and Hong Kong are included - and with further links into selected important cities in South Asia, the Arab Gulf, South America and North America. Toronto is an extreme excluded city for the European firms in this component.

The key features of the small Scandinavian common strategy are as follows.

- There are three firms pursuing this strategy, all northern European banks.

- There are just two command cities: Stockholm and Oslo (Table 1).

- The geography of this service provision is very distinctive, including 12 highest category cities (Figure 4b). These include the five home-region cities in the data (three strictly Scandinavian (Copenhagen, Oslo and Stockholm) plus Helsinki and Riga).

- The global-outreach extends this 'northern rim' pattern to the Americas by including three Canadian cities as well as New York, Luxembourg and Singapore as highest category cities. There is lesser representation in other continents; the most interesting is Nairobi, a key Non-governmental Organisation (NGO) centre (Taylor 2004b) for Scandinavian international development policies. It is also noteworthy 
that this component has most extreme excluded cities: Mumbai and Delhi plus Boston.

This really is an intriguing common strategy labelled for its home-region, but the label also being meaningfully reflected in a distinctive global-reach (see also Schmitt and Smas 2012).

It is not entirely clear why these two different strategies have developed in Europe. Although there is some overlap, it is the separation between the service maps that are most striking: the European strategy misses out Scandinavian cities and the Scandinavia strategy misses out German and southern European cities.

\section{Alternative Commonwealth strategies}

One of the surprises in the initial analyses of service values matrices was the appearance of a Commonwealth component (Taylor et al. 2002a). Not generally associated with business services, this political relict of British imperialism does actually incorporate continuing cultural links that are reflected in early internationalising business strategies now enveloped by contemporary globalisation. In this latest analysis, we find two Commonwealth strategies associated with erstwhile British dominions at opposite ends of the Earth. Both common strategies are minor ones (Table 1) but still interesting in their expression of historical connections.

The key features of the Australasia/Commonwealth common strategy are as follows.

- There are eight firms pursuing this Commonwealth, largely financial services firms.

- As would be expected, its two main command cities are Sydney and Melbourne; the interesting other command city is Johannesburg (Table $1)$.

- The servicing geography is very straightforward (Figure 5a) with all five home-region cities in the data in the highest service category scores. 
- The global-outreach includes other important Commonwealth cities from across the world, except in Canada (Toronto is actually an extremely excluded city), and North America generally is only represented weakly by one city, New York. All UK cities in the data are included in this geography, but no other European cities.

For an Australasia strategy, the surprise is no major presence of Pacific Asian cities beyond ex-British Singapore and Hong Kong.

The key features of the Canada/Commonwealth common strategy are as follows.

- There are five firms pursuing this strategy, largely financial services firms.

- As expected, Toronto dominates as command city; the interesting other command city is Mumbai (Table 1).

- In the servicing geography, all four home-region cities in the data, have highest category scores.

- In the global-outreach, Boston and London are in the highest score category, along with three Indian cities (Figure 5b). With the two other Indian cities in the data being included in this servicing geography, this strategy differs from the Australian one through its more spatially concentrated pattern. There is no representation in Australasia or Africa, only Chicago features weakly in the rest of the Americas (Miami appears as an extreme excluded city), there is also only Manama featuring weakly in the Middle East, and although Pacific Asia includes two cities, these are also weakly featured. In the UK only English cities are included in the servicing geography, but there are two other European cities.

Having Commonwealth common strategies still seems surprising, even more so in 2010, through discovering two quite distinct examples. This provides a reminder that business location strategy is never a simple matter of economic 
advantage; other connections have roles to play in constructing economic opportunities to respond to.

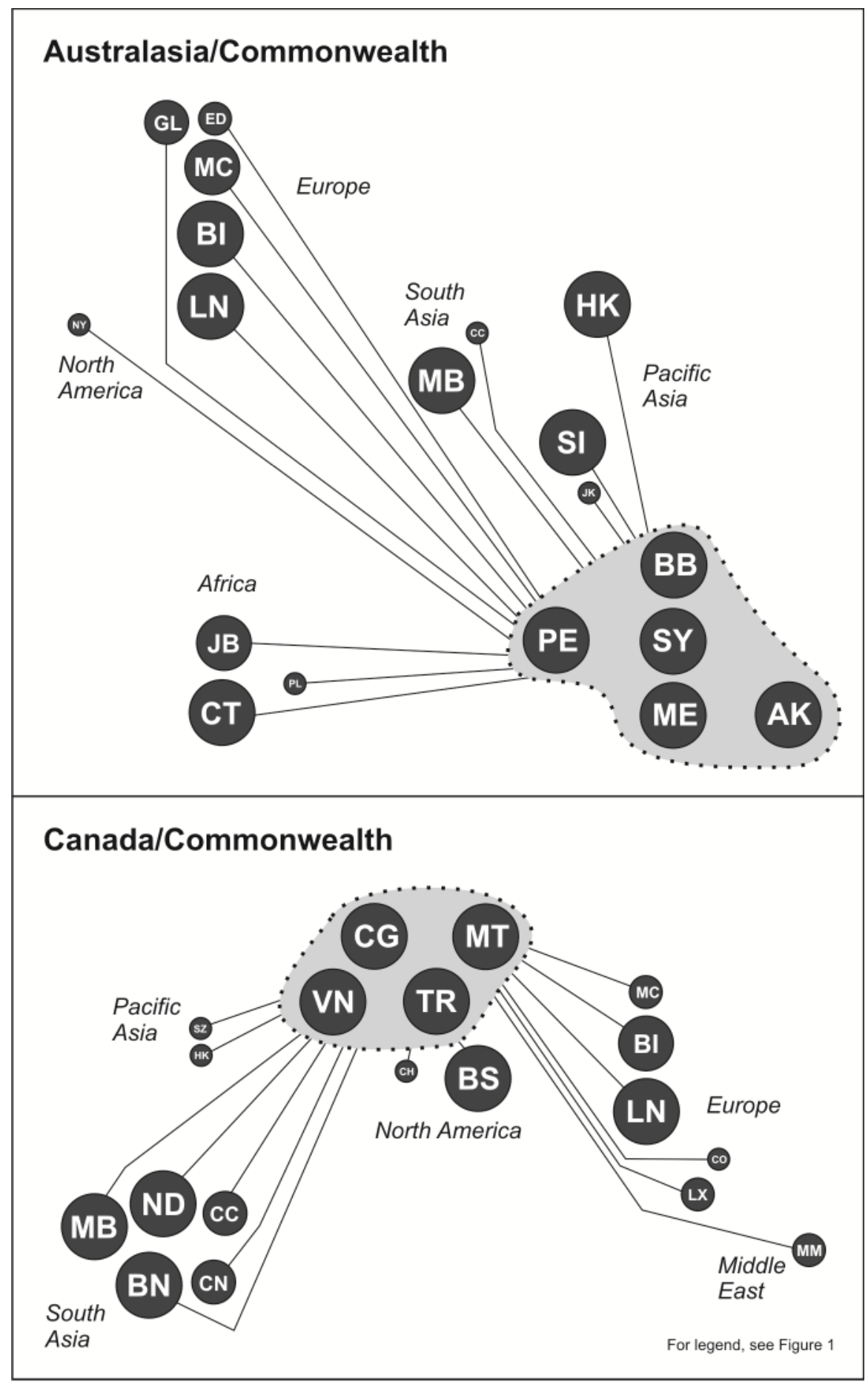

Figure 5 Commonwealth strategies. Note: City codes are given in the Appendix and the key is in Figure 1 


\section{Comparative geography}

The method of paired comparisons is particularly insightful for the 2010 PCA results, but there are additional things to be said using overall comparisons across the ten common strategies. Table 2 has been constructed for this task. For each common strategy, cities are divided between home-region and global-outreach and their scores compared. In addition, for the home-regions, the total number of cities is given to show the degree to which each location strategy is inclusive of its home-regional cities. However, the main purpose of this table is to show variations in the amount of servicing carried out in the home-region relative to the global-outreach for each common strategy.

The first point to make is that if we were ever tempted to interpret globaloutreach as a minor geographical add-on to an otherwise traditional regional formation, the final column of Table 2 sets us right: global-outreach contributes more servicing than home-region in a majority of the common strategies. Even the lowest proportion of servicing for global-outreach is nearly 15 per cent, which is by no means insignificant. Looking at the range of values, the three lowest percentages for global-outreach represent what have been identified as the key 'globalisation arenas' in the making of a globalising world (USAL intensive, Pacific Asia, Europe) (Taylor 2004b). These are regions with their own major advanced producer service firms strongly ensconced in their own important world arena. In contrast, the highest percentages for global-outreach are largely for strategies from smaller homeregions: the two Commonwealth strategies and Scandinavia. However, there is one major exception: the second largest percentage of servicing from the global-outreach is for USAL extensive; this is a very distinctive location strategy in many ways, and seems to represent a particular strong move to globalisation from the traditional central region of the world economy.

Conversely we should not under-value the home-region in these globalisation strategies: for all common strategies the average service value for homeregion cities is larger than for global-reach cities. This is particularly the case for the four smallest home-regions where all cities provide high levels of service. Thus overall the message of these comparisons is to confirm the 
importance of both home-region and global-outreach. Between them they constitute integrated spatial organisations that divide globalisation processes into a new regional formation.

\section{Concluding discussion}

We began this paper by relating our world regional geography to moves towards more fuzzy and messy tendencies in discussions and analyses of regions that have mainly dealt with regions at sub-national scales. We have taken the spirit of such ideas forward to create a very fuzzy and messy worldwide regional analysis.

The starting point of this concluding discussion is to note just how unusual it is to be so messy in global regional depictions. Dividing up the world has been a supremely territorialist endeavour with strong political overtones, starting with early imperialist and strategic geographies before later statistical analyses of states such as Russett's (1967) regionalisation based on UN votes. But descriptions of economic patterns have been equally territorialist and statebased led by the UN's ubiquitous statistical analyses identification of categories of 'development'. And of course, undergirding much of this work there has been a continuing production of world geography texts based upon regionalisations that usually combine economic, cultural and environmental considerations. More recently, this regional tradition has been reinterpreted by Lewis and Wigen: in their more 'refined world regional scheme' (1997, 186-7) they identify 14 world regions, eschewing states as building blocks, and with pointers to some internal differences. But the end result remains resolutely territorialist, a world of definitive boundaries emphasising the differences between peoples. It is this Hartshornian legacy of areal differentiation transposed to global differentiation that can be harnessed to political ends as in Huntington's $(1993,1996)$ infamous 'clash of civilizations'. He proposes an equally 'refined' and quite subtle regionalisation with 'in-between' categories, but the message is a basic 'territory equals conflict' argument, founded on realist International Relations. We are sorely in need of non-territorialist world regionalisations based upon connections rather than divisions. This is what 
our world regional geography as practised by advanced producer service firms provides.

To say that our regionalisation is something completely different is quite an understatement: we replace neat territorialism with untidy connections. Regional labels are provided by home-regions, but the subsequent regional content always includes an outreaching global pattern of important cities. In addition there is much overlap, not at the 'edges' as in territorial thinking, but right at the centre across the home-regions themselves. This is the basis of our regional interpretations of the tenfold regionalisation presented in pairs: USAL globalisations come in two varieties despite sharing the same homeregion; and there are different but not separate American, Pacific Asian, European and Commonwealth regions. It is the Pacific Asian example that is the most instructive here. In territorialist regionalisation, this part of the world is typically divided into 'East Asia' and 'South East Asia' (e.g. Lewis and Wigen 1997), but we have separated out Chinese cities as distinctive. In our analysis it is Japanese firms that unite these two territorial regions as 'Pacific Asia', while Chinese firms are coincidently forming their own region specifically excluding Tokyo. Neither traditional analysis separating East and South East Asia, nor our previous combining them into one Pacific Asian region seem adequate: they both miss the very large cuckoo in the nest: China is both within and separate from Pacific Asia. How's that for geographical messiness!

One final point needs to be made: we have created our regional geography in the spirit of Agnew's $(2012,10)$ multiple 'regional logics' rather than proposing a 'singular logic'. We have provided a messy regionalisation based upon just one set of globalising agents, leading APS firms. Following Sassen (1991), this is justified by the importance of this economic sector in economic globalisation through these firms' strategic uses of cities. Thus we can interpret our regionalisation as a basic structure of the contemporary world economy, but economic globalisation is much more complex than this single regional framework (Coe et al. 2004). There are myriad other globalising agents producing other regional geographies designed for their specific 
purposes. It follows that we should not just appreciate the messiness of our results but also respect the complexity that is the world economy. Our regionalisation still leaves much of the world and its people 'off the map' as Jennifer Robinson (2002) tells it; this is in keeping with our regionalisation not being all-inclusive as in traditional world regional geographies. Thus it is important to interpret our regionalisation as a specific formation, not a general offering as aspired to in most traditional regional geography. But we do contend it to be one of the more important regional geographies amongst the many being created by early twenty-first century global practices.

\section{References}

Agnew J A 2012 Arguing with regions Regional Studies iFirst 1-12 doi:10.1080/00343404.2012.676738

Allen J, Massey D and Cochrane A 1998 Rethinking the region Routledge, London

Amin A 2004 Regions unbound: towards a new politics of place Geografiska Annaler 86 33-44

Burn G 2000 The state, the City and the Euromarkets Review of International Political Economy 6 225-61

Castells, M 1996 The rise of the network society Blackwell, Oxford

Coe N M, Hess M, Yeung H W-c, Dicken P and Henderson J 2004 'Globalizing' regional development: a global production networks perspective Transactions of the Institute of British Geographers 29, 468-84

Derudder B, Taylor P J, Ni P, De Vos A, Hoyler M, Hanssens H, Bassens D, Huang J, Witlox F, Shen W and Yang X 2010 Pathways of change: shifting connectivities in the world city network, 2000-08 Urban Studies 47, 1861-77 
Derudder B, Taylor P J, Witlox F and Catalano G 2003 Hierarchical tendencies and regional patterns in the world city network: a global urban analysis of 234 cities Regional Studies 37, 875-96

Florida R 2008 Who's your city? Basic Books, New York

Friedman T L (2005) The world is flat Farrar, Straus and Giroux, New York

Hanssens H, Derudder B, Taylor P J, Hoyler M, Ni P, Huang J, Yang X and Witlox F 2011 The changing geography of globalized service provision, 2000-2008 The Service Industries Journal31, 2293-307

Harrison J 2008 The region in political economy Geography Compass 2 81430

Huntington S 1993 The clash of civilizations? Foreign Affairs 72 23-49

Huntington S 1996 The clash of civilizations and remaking the world order Simon and Schuster, New York

Jonas A E G 2012 Region and place: regionalism in question Progress in Human Geography 36 263-72

Jones M 2009 Phase space: geography, relational thinking, and beyond Progress in Human Geography 33 487-506

Kynaston D 2011 City of London: the history Chatto \& Windus, London

Lewis M W and Wigen K E 1997 The myth of continents University of California Press, Berkeley, CA

Liu X and Derudder B 2012 Two-mode networks and the interlocking world city network model: a reply to Neal Geographical Analysis 44 171-3 
Massey D 1979 In what sense a regional problem? Regional Studies 13 23343

Massey D 1993 Power-geometry and a progressive sense of place in Bird J, Curtis B, Putnam T, Robertson G and Tickner L eds Mapping the futures: local cultures, global change Routledge, London 60-70

Paasi A 1986 The institutionalization of regions: a theoretical framework for understanding the emergence of regions and the constitution of regional identity Fennia 164 105-46

Paasi A 2004 Place and region: looking through the prism of scale Progress in Human Geography 28 536-46

Robinson J 2002 Global and world cities: a view from off the map International Journal of Urban and Regional Research 26, 531-54

Rummel R J 1970 Applied factor analysis Northwestern University Press, Evanston

Russett B M 1967 International regions and the international system Rand McNally, Chicago

Sassen S 1991 The global city Princeton University Press, Princeton, NJ

Schmitt P and Smas L 2012 Nordic 'intercity connectivities' in a multi-scalar perspective Nordregio Working Paper 2012:7 Nordregio, Stockholm (http://www.nordregio.se) Accessed 22 June 2012

Scott A J 1998 Regions and the world economy Oxford University Press, Oxford 
Taylor P J 2001 Specification of the world city network Geographical Analysis $33181-94$

Taylor P J 2004a Regionality in the world city network International Social Science Journal $181361-72$

Taylor P J 2004b World city network: a global urban analysis Routledge. London

Taylor P J 2011 Advanced producer services in the world economy in Taylor P J, Ni P, Derudder B, Hoyler M, Huang $\mathbf{J}$ and Witlox F eds Global Urban Analysis: A Survey of Cities in Globalization Earthscan, London 22-39

Taylor P J and Aranya R 2008 A global "urban roller coaster"? Connectivity changes in the world city network, 2000-2004 Regional Studies 42 1-16

Taylor P J and Walker D R F 2001 World cities: a first multivariate analysis of their service complexes Urban Studies 38 23-47

Taylor P J, Catalano G and Walker D R F 2002a Measurement of the world city network Urban Studies 39 2367-76

Taylor P J, Catalano G and Walker D R F 2002b Exploratory analysis of the world city network Urban Studies 39 2377-94

Taylor P J, Hoyler M, Pain K and Vinciguerra S 2011 Extensive and intensive globalizations: explicating the low connectivity puzzle of US cities using a city-dyad analysis GaWC Research Bulletin 369 (http://www.lboro.ac.uk/gawc/rb/rb369.html) Accessed 28 November 2011

Taylor P J, Hoyler M, Walker D R F and Szegner M J 2001 A new mapping of the world for the new millennium The Geographical Journal 167 213-22 
Wójcik D 2011 The dark side of NY-LON: financial centres and the global financial crisis Working Papers in Employment, Work and Finance 11-12 School of Geography and the Environment, Oxford University (http://ssrn.com/abstract=1890644) Accessed 28 November 2011 
Table 1 Command cities for each common strategy

\begin{tabular}{|l|c|}
\hline \multicolumn{1}{|c|}{ USAL Intensive } & HQ sum \\
\hline New York & 9.8 \\
\hline Chicago & 4.8 \\
\hline London & 1.9 \\
\hline Pittsburgh & 1.4 \\
\hline Los Angeles & 1.4 \\
\hline Toronto & 1.3 \\
\hline Boston & 1.1 \\
\hline Philadelphia & 0.8 \\
\hline Miami & 0.7 \\
\hline Washington & 0.7 \\
\hline Columbus & 0.6 \\
\hline Detroit & 0.6 \\
\hline Baltimore & 0.5 \\
\hline San Francisco & 0.5 \\
\hline
\end{tabular}

\begin{tabular}{|l|c|}
\hline \multicolumn{1}{|c|}{ USAL Extensive } & HQ sum \\
\hline New York & 8.2 \\
\hline London & 3.3 \\
\hline Chicago & 1.9 \\
\hline Paris & 1.1 \\
\hline
\end{tabular}

\begin{tabular}{|l|c|}
\hline \multicolumn{1}{|c|}{ Pacific Asia } & HQ sum \\
\hline Tokyo & 5.3 \\
\hline Beijing & 1.9 \\
\hline Seoul & 1.2 \\
\hline London & 0.9 \\
\hline Singapore & 0.7 \\
\hline Paris & 0.5 \\
\hline Melbourne & 0.5 \\
\hline
\end{tabular}

\begin{tabular}{|l|c|}
\multicolumn{1}{c|}{ Americas } & HQ sum \\
\hline New York & 4.7 \\
\hline Toronto & 1.0 \\
\hline Chicago & 0.6 \\
\hline Dublin & 0.6 \\
\hline Atlanta & 0.5 \\
\hline Charlotte & 0.5 \\
\hline Brussels & 0.5 \\
\hline Zurich & 0.5 \\
\hline Boston & 0.5 \\
\hline
\end{tabular}

\begin{tabular}{|l|c|}
\hline \multicolumn{1}{|c|}{ Europe } & HQ sum \\
\hline London & 3.1 \\
\hline Milan & 1.1 \\
\hline Boston & 1.0 \\
\hline Madrid & 1.0 \\
\hline Munich & 0.7 \\
\hline Trieste & 0.5 \\
\hline Frankfurt & 0.5 \\
\hline Turin & 0.5 \\
\hline Paris & 0.5 \\
\hline Istanbul & 0.5 \\
\hline
\end{tabular}

\begin{tabular}{|l|c|}
\hline \multicolumn{1}{|l|}{ Australasia/Commonwealth } & HQ sum \\
\hline Sydney & 1.5 \\
\hline Melbourne & 1.3 \\
\hline Munich & 0.6 \\
\hline Johannesburg & 0.5 \\
\hline London & 0.5 \\
\hline
\end{tabular}

\begin{tabular}{|l|c|}
\hline \multicolumn{1}{|c|}{ Latin America } & HQ sum \\
\hline São Paulo & 1.3 \\
\hline Madrid & 0.9 \\
\hline Brasilia & 0.7 \\
\hline
\end{tabular}

\begin{tabular}{|l|c|}
\hline \multicolumn{1}{|c|}{ Canada/Commonwealth } & HQ sum \\
\hline Toronto & 1.6 \\
\hline Boston & 0.6 \\
\hline Mumbai & 0.5 \\
\hline
\end{tabular}

\begin{tabular}{|l|c|}
\hline \multicolumn{1}{|c|}{ Scandinavia } & HQ sum \\
\hline Stockholm & 1.3 \\
\hline Oslo & 0.5 \\
\hline
\end{tabular}

\begin{tabular}{|l|c|}
\multicolumn{1}{|c|}{ China } & HQ sum \\
\hline Shenzhen & 0.7 \\
\hline Shanghai & 0.7 \\
\hline Beijing & 0.5 \\
\hline
\end{tabular}


Table 2 Geographical comparisons between common strategies

\begin{tabular}{|c|c|c|c|c|c|c|c|}
\hline \multirow{2}{*}{$\begin{array}{l}\text { Common } \\
\text { strategy }\end{array}$} & \multicolumn{4}{|c|}{ Home-region } & \multicolumn{3}{|c|}{ Global-outreach } \\
\hline & Cities & $\begin{array}{l}\text { Service } \\
\text { cities }\end{array}$ & $\begin{array}{l}\text { Ave. } \\
\text { service } \\
\text { (score) }\end{array}$ & $\begin{array}{l}\% \text { total } \\
\text { service }\end{array}$ & $\begin{array}{c}\text { Service } \\
\text { cities }\end{array}$ & $\begin{array}{c}\text { Ave. } \\
\text { service } \\
\text { (score) }\end{array}$ & $\begin{array}{l}\% \text { total } \\
\text { service }\end{array}$ \\
\hline USAL Intensive & 28 & 16 & 2.09 & 85.21 & 6 & 0.97 & 14.79 \\
\hline $\begin{array}{l}\text { USAL } \\
\text { Extensive }\end{array}$ & 28 & 5 & 1.42 & 14.18 & 47 & 0.92 & 85.82 \\
\hline Americas & 45 & 25 & 1.25 & 61.56 & 20 & 0.98 & 38.44 \\
\hline Latin America & 13 & 10 & 1.88 & 48.89 & 16 & 1.23 & 51.11 \\
\hline Pacific Asia & 16 & 16 & 2.15 & 77.41 & 11 & 0.91 & 22.59 \\
\hline China & 5 & 5 & 3.46 & 46.20 & 21 & 0.96 & 53.80 \\
\hline Europe & 38 & 28 & 1.48 & 84.67 & 7 & 1.07 & 15.33 \\
\hline Scandinavia & 5 & 5 & 2.44 & 27.44 & 26 & 1.24 & 72.56 \\
\hline $\begin{array}{l}\text { Australasia/ } \\
\text { Commonwealth }\end{array}$ & 5 & 5 & 3.41 & 14.09 & 14 & 1.49 & 85.91 \\
\hline $\begin{array}{l}\text { Canada/ } \\
\text { Commonwealth }\end{array}$ & 4 & 4 & 2.65 & 30.52 & 15 & 1.61 & 69.48 \\
\hline
\end{tabular}


Appendix: City codes for figures

\begin{tabular}{|c|c|c|c|c|c|c|c|}
\hline AA & Amman & CS & Casablanca & LG & Lagos & $\mathrm{RI}$ & Riga \\
\hline$A D$ & Abu Dhabi & CT & Cape Town & LM & Lima & RJ & Rio de Janeiro \\
\hline AK & Auckland & CV & Cleveland & LN & London & $\mathrm{RM}$ & Rome \\
\hline$A L$ & Almaty & DA & Dallas & LX & Luxembourg & $\mathrm{RY}$ & Riyadh \\
\hline AM & Amsterdam & $\mathrm{DB}$ & Dublin & $\mathrm{MB}$ & Mumbai & SA & Santiago \\
\hline AN & Antwerp & $\mathrm{DH}$ & Doha & $\mathrm{MC}$ & Manchester & SD & San Diego \\
\hline AS & Athens & DS & Düsseldorf & MD & Madrid & SE & Seattle \\
\hline AT & Atlanta & DT & Detroit & $\mathrm{ME}$ & Melbourne & SF & San Francisco \\
\hline BA & Buenos Aires & $\mathrm{DU}$ & Dubai & $\mathrm{MI}$ & Miami & SG & Stuttgart \\
\hline BB & Brisbane & DV & Denver & ML & Milan & $\mathrm{SH}$ & Shanghai \\
\hline $\mathrm{BC}$ & Barcelona & ED & Edinburgh & MM & Manama & SI & Singapore \\
\hline $\mathrm{BD}$ & Budapest & FR & Frankfurt am & MN & Manila & SJ & San José \\
\hline $\mathrm{BE}$ & Belgrade & & Main & $\mathrm{MO}$ & Monterrey & SK & Stockholm \\
\hline$B G$ & Bogota & $\mathrm{GL}$ & Glasgow & MP & Minneapolis & $\mathrm{SL}$ & Saint Louis \\
\hline $\mathrm{BI}$ & Birmingham & GN & Geneva & MS & Moscow & SN & San Juan \\
\hline BJ & Beijing & GT & Guatemala City & $\mathrm{MT}$ & Montreal & $\mathrm{SO}$ & Sofia \\
\hline BK & Bangkok & $\mathrm{GZ}$ & Guangzhou & MU & Munich & $\mathrm{SP}$ & São Paulo \\
\hline $\mathrm{BL}$ & Berlin & $\mathrm{HA}$ & Hanoi & MV & Montevideo & ST & Santo Domingo \\
\hline $\mathrm{BM}$ & Baltimore & $\mathrm{HC}$ & Ho Chi Minh & $\mathrm{MX}$ & Mexico City & SU & Seoul \\
\hline BN & Bangalore & & City & $\mathrm{NC}$ & Nicosia & SY & Sydney \\
\hline BR & Brussels & $\mathrm{HK}$ & Hong Kong & ND & New Delhi & $\mathrm{SZ}$ & Shenzhen \\
\hline BS & Boston & $\mathrm{HL}$ & Helsinki & NR & Nairobi & $\mathrm{TA}$ & Tel Aviv \\
\hline BT & Beirut & $\mathrm{HB}$ & Hamburg & NY & New York & TK & Tokyo \\
\hline BU & Bukarest & HS & Houston & $\mathrm{OK}$ & Osaka & TM & Tampa \\
\hline BV & Bratislava & IS & Istanbul & OS & Oslo & TP & Taipei \\
\hline $\mathrm{CA}$ & Cairo & $\mathrm{JB}$ & Johannesburg & $\mathrm{PA}$ & Paris & TR & Toronto \\
\hline $\mathrm{CC}$ & Calcutta & JD & Jeddah & PB & Pittsburgh & TU & Tunis \\
\hline CG & Calgary & JK & Jakarta & PD & Portland & VI & Vienna \\
\hline $\mathrm{CH}$ & Chicago & $\mathrm{KC}$ & Kansas City & PE & Perth & VN & Vancouver \\
\hline $\mathrm{Cl}$ & Cincinnati & $\mathrm{KL}$ & Kuala Lumpur & $\mathrm{PH}$ & Philadelphia & WC & Washington \\
\hline CL & Charlotte & $\mathrm{KR}$ & Karachi & $\mathrm{PL}$ & Port Louis & WS & Warsaw \\
\hline $\mathrm{CN}$ & Chennai & $\mathrm{KU}$ & Kuwait & PN & Panama City & $Z G$ & Zagreb \\
\hline $\mathrm{CO}$ & Cologne & $\mathrm{KV}$ & Kiev & $\mathrm{PO}$ & Palo Alto & ZU & Zurich \\
\hline $\mathrm{CP}$ & Copenhagen & LA & Los Angeles & PR & Prague & & \\
\hline CR & Caracas & LB & Lisbon & $\mathrm{PX}$ & Phoenix & & \\
\hline
\end{tabular}

